Keywords: distance education, law enforcement officer, legal reality, human rights, philosophy of law, "people of the past", "bioputer", freedom, social and humanitarian disciplines.

DOI: $10.33766 / 2524-0323.90 .278-287$

УДК 340.15:343.35

В. В. Пилипенко,

кандидат історичних наук,

старший викладач кафедри

соціально-гуманітарних дисциплін

Луганського державного університету внутрішніх справ імені Е. О. Дідоренка

(м. Севєродонецьк, Україна)

e-mail: viktoriiapylypenko1991@gmail.com

iDhttps:// orcid.org/0000-0002-2555-542X

\title{
КОРУПЦЯ НА УКРАЇНСЬКИХ ЗЕМЛЯХ ЯК ПИТАННЯ КУРСУ ІСТОРІЇ ДЕРЖАВИ ТА ПРАВА
}

Статтю присвячено аналізу способів отримання протиправної вигоди на українських землях у залежності від їх територіально-політичної приналежності в різні періоди історіїУкраїни та розвитку правового регулювання попередження корупційної складовоїв діяльності посадових осіб чи органів державної влади. Досліджено основні прояви корупщії від Київської Русі до розпаду СРСР; особливу увагу приділено розгляду системи кормлінь, отриманню протиправної вигоди у вигляді подарунків та презентів вищими посадовими особами, тотальній корумпованості радянського суспільства, що проявлялося у вигляді блату, приписок тощо. Установлено, що звернення до цього матеріалу та аналіз історичних джерел у контексті виявлення та протидії корупщії сприяє виявленню, міжпредметних зв'язків, дозволяе краще засвоїти відповідні професійні знання як із дисциплін гуманітарного циклу у ЗВО МВС України, так і спеціальних державно-правових, а також формувати активну громадянську позищію в протидії негативним суспільним явищам.

Ключові слова: корупщія, хабар, блат, підкуп, кормління, партійна номенклатура, протиправна вигода, професійні знання, громадянська позищія.

Постановка проблеми. Наявність соціального замовлення на висококваліфікованих фахівців правоохоронної сфери, здатних швидко трансформувати й синтезувати предметні знання в нові реалії, організовувати мисленнєвий процес у стресових ситуаціях, що потребують поєднання всіх набутих умінь і навичок, актуалізує проблему організації інтегрованого навчання. Однак його запровадження гальмується загальноприйнятим дтя вищої школи протиріччям між єдністю (загальною спрямованістю як цілісністю) і диференщіацією (як професіоналізацією, часто-густо доволі вузькою) загальної мети підготовки фахівців, що проявляється в підходах до складання навчальних планів. Зосередженість на тематичній наповнюваності кожної дисципліни окремо призводить до фрагментарності набутих студентами знань, що в зрештою зумовлює зниження теоретичної підготовленості випускників і менший ступінь підготовленості практичної, тобто конкурентоздатності на ринку пращі в порівнянні із фахівцями міжгалузевої спеціалізації.

(C) Пилипенко В. В., 2020 
Вирішити протиріччя між попитом на всебічно обізнаного співробітника з активною громадянською позищією в протидії негативним суспільним явищам, здатного оперувати як загальними, так і вузькоспеціалізованими термінами, орієнтувати викладачів на перевірку рівня засвоєння знань не тільки зі своєї дисципліни (особливо якщо ця дисципліна входить до переліку спеціальних) покликана координація навчання (те, що традищійно визначається, як «міжпредметні зв' язки», але дещо поглиблені в професійному спрямуванні). Відмінністю між координацією навчання та інтегращією $є$ те, що остання передбачає поступове об'єднання кількох навчальних предметів в один, а координація лише встановлює ретельно розроблений взаємозв' язок між темами та практичними вправами навчальних предметів.

Детального розгляду потребує саме питання координації навчальних предметів теоретичного та історичного циклу зі спеціальними державно-правовими дисциплінами, що викладають у закладах вищої освіти зі специфічними умовами навчання, де здійснюється підготовка кадрів юристів і правоохоронщів для системи MBC України. Найперше увагу потрібно звернути на налагодженні міжпредметних зв'язків між історією держави та права й такими спеціально-правовими дисциплінами, як адміністративне, цивільне, кримінальне право, криміналістика тощо. Подібна координація є взаємоприйнятною і, так би мовити, взаємовигідною, адже забезпечує історичну дисципліну законодавчим фактичним матеріалом, тоді як правові - широким спектром прикладів і підгрунтям для юридичної компаративістики як загального методологічного підходу. У цілому це, як удається, дозволить вирішити проблему підвищення якості підготовки спеціалістів відповідного профілю (спеціальності).

Аналіз останніх досліджень і публікацій. Корупщія, як антисоціальне явище, $є$ предметом дослідження вітчизняних істориків та юристів, а також представників інших наукових спеціальностей. Зокрема, вивченню витоків державної зради, зумовленої підкупом чи хабарем, приділяли увагу М. Бакунін, О. Дудоров, А. Русяєва, М. Маськовіт. Історико-теоретичні та практичні аспекти боротьбиз корупщією в Київській Русі, Литовсько-Польській державі досліджували Л. Войтович, Ю. Походзіло. Розгорнутий аналіз поняття корупщії та його еволюції від доби Гетьманщини до перебування українських земель у складі СРСР подається в працях А. Боровика, Н. Жаленко, В. Утвенко, Н. Левищької, В. Гаращука та ін. Однак, попри значні здобутки історіографіï, залишається маловивченою питання практичного застосування здобутих знань з історії корупщії на практищі, а саме, у якості додаткової аргументації під час викладання теоретичного матеріалу з різних галузей права.

Формулювання цілей. Метою статті є дослідження особливостей міжпредметної координащії на прикладі вивчення питання еволющії розуміння корупщії на українських землях від початків державності до сьогодення в курсі «Історія держави та права».

Виклад основного матеріалу. Корупія, як соціально-економічне й політикоправове явище, є характерним для більшості держав світу і найчастіше проявляється в зловживанні посадовими обов' язками в особистих корисних цілях або в інтересах певних груп та виражається в підкупі, фаворитизмі, клієнтелізмі, хабарництві, розкраданні державного майна тощо.

Неправомірна вигода, як обов'язкова складова корупції, сягає своїм корінням часів перших державних утворень на території України. Документальне підтвердження фактів існування хабарництва знаходимо в III ст. до н.е., коли в Північному 
Причорномор'ї існували грецькі міста-держави. Так у «Присязі громадянина Херсонеса» містилося зобов’ язання «не давати і не приймати дару на шкоду міста і громадянам» [1, с.15]. Попри те й досі тривають наукові дискусії з приводу дати й точної назви «Присяги. .. ». Білышість істориків погоджуються з тим, що вона носить екстраординарний характер, будучи укладеною ad hoc після спроби повалити демократичний устрій [2, с. 193]. Аналіз тексту «Присяги...» не лише засвідчує рівень розвитку демократичних інститутів у грецьких містах-державах Північного Причорномор'я, але й може слугувати історико-правовим прикладом відповідальності чиновника за порушення присяги в різних сферах матеріального і процесуального права [3, с. 25].

Перехід Херсонеса в V ст. під владу Східної Римської імперії (Візантії) тотальна корупщія. Фігурантами корупційних справ ставали не лише чиновники, але й служителі церкви, що підривало основи державності зсередини, роблячи Херсонес (Корсунь) «легкою здобиччю» для завойовників. Свідченням того, що свавілля чиновників і церковників розхитують єдність держави, сприяючи зазіханням на ії територіальну цілісність, є захоплення Херсонеса (Корсуня) дружиною князя Володимира Святославовича під час Херсонеської війни 987 - 988 рр. Відомо, що це було зроблено шляхом викупу у священника Анастаса схеми водогону [4, с. 9]. Отримана таким, фактично злочинним шляхом інформація (хоча на той час це можна інтерпретувати і як «воєнну хитрість) була використана києво-руським князем для безпосереднього шантажу візантійських імператорів Василя II та Костянтина VIII, з метою змушення дати дозвіл на шлюб Володимира з їхньою сестрою Анною. Таке одруження Володимира Святославовича, якому передувало прийняття християнства, надавало Київській Русі міжнародного визнання й змінювало загальнополітичний вектор, що здійснювався відтепер під візантійським впливом [4, с. 10]. Як бачимо, у даному випадку підкуп, як протиправне діяння, на той час мав досить неоднозначні суперечливі наслідки. Так один із цих наслідків можна тлумачити як такий, що створив для двох держав в цілому позитивне поле для розвитку, тому потребує подальшого додаткового вивчення істориками та юристами. Можна сказати лише одне, що цей позитивний прояв не є результатом корупційних дій, а наступним втіленням політичної волі у сфері державотворення й вектору розвитку країни, у цьоу випадку Володимира Святославовича.

Інший приклад, який можна тлумачити як наявність отримання неправомірної вигоди у києворуському суспільстві XI - XII ст., надає «Руська Правда» Ярослава Мудрого. У джерелі києво-руського права, що складалося впродовж XI - XII ст., містяться попередження недопустимості використання віри для особистого збагачення бояр чи дружинників. Віра - штраф за скоєний злочин, частина якого передавалась потерпілому, а інша - поповнювала казну. Збирали штраф вірники, які утримувалися за рахунок місцевого населення. Щоправда, і це слід зазначити: «Руська Правда» намагалася убезпечити населення від маніпуляцій щодо визначення суми штрафів та шляхів їх погашення, увівши обмеження в часі перебування чиновників на ввіреній їм території. Також потрібно наголосити, що окремо в джерелі також йшла мова про попередження хабарнищтва шляхом недопущення «виправдання нечестивого заради мзди і не віднімання від правдивого правди» [5].

Наведені приклади, як удається, можуть вельми пожвавити вивчення проблем корупщії, наприклад, і в курсі кримінального права, зважаючи на складності цього 
питання, що часто виходить за межі суто правового поля і стосується багатьох аспектів життя народів і свідомості людей.

Цікавим під час вивчення фінансового та податкового права в період роздробленості Київської Русі XII - XIV ст. може бути досвід організації системи кормлінь винагороди бояр, які здійснюють судово-адміністративні функції, шляхом надання прав обкладати податками населення підвладних їм територій на свою користь (ця традищія залишалася багато століть, що надає підстави тлумачити цей факт, наприклад, як ментальні засади такого явища й сьогодні). «Кормлінщиком» вважалася особа, яка отримала певну територію в «кормління», що жила на повному утриманні місцевого населення за рахунок поборів, збору податків на свою користь. Імовірніше, на думку Ю. Походзіло, щоб отримати «кормління», треба було дати хабар дяку, що розподіляе його [6, с. 72]. Загалом можна зазначити, що, система «кормління» виступала досить яскравим прикладом процесу зародження, формування і функціонування корупщйних систем протягом декількох історичних періодів. Натепер складно визначити однозначну позищію дослідників щодо кваліфікації даної системи, як корупційної або некорупційної за своєю природою, зважаючи на своєрідність кожного історичного періоду. Справа в тім, що сама по собі система «кормління» була санкціонована державою і не може вважатися нелегальною, проте водночас вона ж була джерелом виникнення масштабних зловживань і системних корупщійних практик. Таким чином, тут ми бачимо утворення та функщіонування унікальної системи, яка мала всі ознаки корупійної практики та діяла протягом кількох століть. Особливо виразно класична форма такої корупційної складової була представлена в Російській імперії, на підтвердження чого виступає виданий 1762 р. Катериною II «Маніфест про лихоїмство», де зазначалося, що чиновникам необхідно запровадити фіксовану оплату праці й заборонити «приймати дари від підданих», тобто, фактично йшлося про спроби викоренити традищійне кормління [7, с. 233], що було втіленням впливу на світогляд знаменитої імператрищі ідей європейських просвітителів, з якими (наприклад, Вольтером і Д' Аламбером) вона мала особисте листування.

«Оксамитовий» період перебування українських земель XIV-XVI ст. у складі князівства Литовського характеризується найнижчим рівнем корумпованості органів влади. Однак, при цьому розповсюдженим способом отримання незаконної вигоди, відповідно до артикулів Першого Литовського статуту 1529 р., можна вважати присвоєння частини коштів, що виділялися на будівництво укріплень та фортець, а також встановлення суддями судових зборів вище за норму, регламентовану законодавством [8, с. 249].

Збільшення проявів корупщії, порівняно з попереднім періодом, припадає на кінець XVI ст. - початок XVII ст., коли більшість українських земель перебувала у складі Речі Посполитої. «Катехізес», написаний просвітником Симоном Будним у 1562 р., рясніє прикладами зловживання владою та поборами чиновників. Цікавим $€$ те, що автор не наполягає на суворому покаранні хабарників, вважаючи, що боротися $з$ корупщіонером має веління його совісті [9, с. 10].

У XVII ст. масовою стала заангажованість та продажність суддів. Навіть у королівських судах чиновники могли уникнути покарання за умови наявності покровителя та статків. Тогочасний історик Старовольський так описував правосуддя Речі Посполитої: «У судах у нас завелися нечувані побори, підкупи; наші війти, лавники, 
бурмистри - все продажні, а про донощиків, які підводять невинних людей в біду, і говорити нема чого. Спіймають багатого, заплутають і засадять до тюрми, та й тягнуть $з$ нього подарунки і хабарі» [10].

Незважаючи на існуючу довгий час серед науковців думку про те, що в період Гетьманщини, завдяки козацькому звичаєвому праву, корупщія була зведена до мінімуму, збереглися документи, що засвідчують протилежне: корупщія була на рівні козацької старшини та проявлялася в привласненні земельних угідь разом із селами. Про надмірне зловживання козацькою старшиною своїм становищем і незаконне заволодіння землею вільних селян, що визнається неприпустимим, ідеться в Конституції Пилипа Орлика 1710 р. Таким чином, текст цієї Конституції, який вивчається в курсі історії держави та права, може слугувати не лише наочним матеріалом для опанування конституційного права, але й може бути використаним для формування задач із права кримінального, земельного, цивільного тощо [11].

Корупщійні схеми, а точніше, такі собі «життєві підходи», розроблялися і звичайними, рядовими козаками, які прагнули отримати дозвіл на роздрібну торгівлю горілкою, тютюном та дьогтем. Тяжкими наслідками військової повинності рядового козацтва було зростання хабарництва в середовищі сотників, які за гроші чи послугу могли звільнити козака від військових походів (що здійснювалися переважно своїм коштом) або інших повинностей [12, с. 126].

Хрестоматійним прикладом під час розгляду порушень норм тогочасного виборчого права є отримання в добу Руйни старшинських посад, а в деяких випадках навіть гетьманської булави за рахунок підкупу голосів козаків-виборців. Вважається, що започаткована ця традищія підкупу й маніпулящій була в 1663 р. на Чорній раді, коли Іван Брюховецький, завдяки демагогії й роздачі подарунків простим козакам, був обраний гетьманом, тим самим заклавши початок фінансовому й політичному втручанню Москви у внутрішні справи Гетьманщини [13].

У XVIII-XIX ст. починають практикувати дарування презентів чиновникам із метою успішного вирішення питань. Чиновники високого рангу із задоволенням могли прийняти в якості «презенту» якісний алкоголь, крупний рогатий скот або вишукану рибу. Універсальним подарунком залишалися тканини, які можна було як відправити для «вирішення питання» до Санкт-Петербургу впливовому надвірному наміснику, так і розрахуватися за послуги з місцевими «клерками». Зазначені способи, а фактично норми взаємодії між державними службовцями та громадянами, можуть бути використані, наприклад, для обгрунтування доцільності посилення дії норм адміністративного права щодо запобігання одержанню неправомірної вигоди або подарунка та поводження з ними тощо.

Запобігання та врегулювання конфлікту інтересів, як невід'ємна прогресивна складова розвитку сучасного адміністративного права, може розглядатися і з позищіі історизму, де ставиться акцент на негативних наслідках, які мали фаворитизм і клієнтилізм у XIX ст. у Російській імперії, включаючи, звісно, й українські землі. Досить згадати зловживання владою боярина Морозова, улюбленця Петра I князя О. Меншикова (саме того, який зруйнував столищю Гетьманщини Батурин), присвоєння значних коштів, що виділялися на заселення Півдня України, Г. Потьомкіним, фаворитом Катерини Другої, та ін. [14, с. 19]. 
Невизнання проблеми корупції в Радянському Союзі, відсутність науково обгрунтованої антикорупщійної політики, тоталітарний характер влади є визначальними факторами іiі розвитку та поширення. Це набуло такого масштабу, що стало невід' ємною складовою життя суспільства. Найбілыш корумпованою була сфера обслуговування. Придбати низку «дефіцитних товарів» можна було лише завдяки хабарю і «блату» - найбілыш популярному типу радянської корупщії. Така форма позаправової взаємодії, з одного боку, відроджувала традищії, що склалися в попередні часи, з іншого - відбивали те фактично жалюгідне становище, у якому перебувала значна кількість населення країни.

Практикували також «приписки» - навмисне подання недійсних даних щодо виконання плану або використання сировини. Наприклад, керівниками бензоколонок чи водіями подавалися некоректні дані використання бензину. «Заощаджений» таким чином бензин використовувався для обміну на чорному ринку, у тому числі й на іноземні товари (найбажаніший «дефіцит»).

Радянське корупщійне минуле $є$ не просто основою «роботи над помилками» для сучасного українського антикорупійного законодавства, але й слугує джерельною базою для вивчення становлення кримінального, кримінально-процесуального права, де, на відміну від законодавства СРСР, існує чітке розмежування класифікації злочинів, в основі яких лежить отримання неправомірної вигоди. Загалом, детальний аналіз реформ у сфері органів державної влади, правоохоронної системи, податкового, фінансового права не можливий без вивчення «гучних» корупційних скандалів у СРСР та проявів корупщї на побутовому рівні. До таких корупщійних скандалів 1970-1980-х років відносять «Справу Єлісєєвського гастронома», «Рибну справу», «Бавовняну справу» тощо [17].

Розгляд таких «гучних» корупщійних справ може бути не лише предметом обговорення для історичних і правових дисциплін, але й використовуватися для вивчення, наприклад, логічного квадрату в курсі «Юридичної логіки». Так само, за принципом логічного квадрату, побудовано моделювання корупційних схем, запропоноване Роуз Аккерман, де в якості фігурантів розглядаються бюрократ (виконавець), конкуренти за державний контракт - клієнти (суб'єкти). Вона розглядає корупщію як економічну поведінку в умовах ризику, пов'язану зі скоєним злочином та можливим покаранням за нього [15, с. 110]. Такі та інші, уже цьогочасні, приклади дозволяють не просто наблизити історичний матеріал до практики майбутньої правоохоронної діяльності, а зробити шляхами такого наближення цілу низку юридичних і спеціальних дисциплін навчального плану пілготовки спеціалістів у ЗВО МВС України.

Висновки. Вивчення навчального курсу «Історія держави та права» передбачає не лише ознайомлення з основними етапами державотворення з характеристикою змін, що відбувалися, але й можливість розгляду конкретних правових явищ від моменту першої їх юридичної фіксації до сьогодення. Така тематична наскрізність дисципліни надає також можливість забезпечити координацію тематичних блоків із відповідними розділами спеціальних правових дисциплін.

У запропонованому короткому дослідженні показано, що тема історії виникнення та протидії корупщії на території України бере свій початок від доби Античності та чітко окреслюється вже у вигляді системи «кормлінь» у Київській Русі, що зумовлювала зловживання владою й неминуче тягла за собою протиправні (навіть у 
розумінні тих часів) корупщійні дії. Детальний розгляд спроб середньовічного правника запобігти тотальній корумпованості державних службовців через введення інституту присяги, значних штрафів, що аналізуються з точки зору їх доцільності під час паралельного викладання таких галузей права, як фінансове йподаткове, сприяє не лише засвоєнню курсантами історичних фактів, але й дає можливість використати такі приклади на творчо-пошуковому рівні вже під час виконання завдань із спеџцисципліни.

Подібна координація репродуктивних знань, набутих під час вивчення історії держави та права, із кримінальним, адміністративним правом тощо, де необхідно задіяти пошуковий рівень інтелекту, стає можливою завдяки подальшому вивченню корупщійних проявів на території українських земель, зокрема під владою Речі Посполитої та Російської імперії.

Позитивна оцінка антикорупційного законодавства сучасної України, білыш зацікавлене вивчення функціональних обов'язків працівників Вищого антикорупційного суду України, Спеціальної антикорупційної прокуратури не можливе без критичної оцінки такого законодавства в радянський період, свідченням про недієвість якого була тотальна корупція на побутовому й загальнодержавному рівні. Дані про найбільш гучні корупщійні скандали в СРСР також можна отримати під час вивчення відповідних тем з історії держави та права.

До цих висновків, як удається, слід додати й моральний аспект професійної діяльності правоохоронщя, оскільки всі описані неправові корупщійні дії є, за визначенням, діями людей, які мають владу і можливість робити боляче іншим, котрі несуть величезні втрати від таких дій. Як зазначає відомий сучасний канадський правознавець Б. Мелкевік, толерантність до несправедливості є загрозою демократії й правам людини (а корупція - це підкреслена несправедливість), а тому сьогодні «ми все більше усвідомлюємо той ступінь насильства, яке може завдати людина, і той біль, який ми можемо генерувати і поширювати серед самих себе і далеко навколо, 3 тих чи інших причин» [16, с. 431].

Перспективами подалышого дослідження має стати й надалі тематична координація історії держави та права з відповідними правовими дисциплінами, передбаченими навчальним планом, 3 метою надання викладанню історії практичного значення й статусу основоположної, що сприяє підготовці висококваліфікованих, усебічно обізнаних правоохоронщів.

\section{Використані джерела:}

1. Гавриленко О. А. Історія держави і права Украӥни: стародавня доба: навч. посіб. Харків: ХНУВС, 2011.64 с.

2. Русяева А. С. О присяге граждан Херсонеса Таврического и загадочном слове

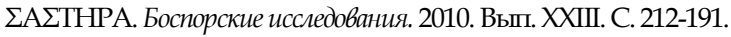

3. Маськовіта М. М. Присяга працівників ОВС України: історико-правовий вимір: дис. ... канд. юрид. наук : 12.00 .01 / Львівський університет внутрішніх справ. Львів, 2017. 224 с.

4. Войтович Л. В. Князь Володимир Святославич (Святий рівноапостольний князь Володимир). Вісник Львівської комериійної академії. Гуманітарні науки. Львів, 2015. Вип.13. С. 7-18.

5. Правда руська. Тексти на основі 7 списків та 5 редакцій / упоряд. С. Юшков. Київ: BУAH, 1935. С. 137-144. URL: http:// litopys.org.ua/oldukr2/oldukr51.htm (дата звернення: 28.05.2020). 
6. Походзіло Ю. М. Становлення податкової функції держави на українських землях у часи Київської Русі та феодальної роздробленості XII - XIV ст. Право та інновації. 2017. № 4(20). C.69-74.

7. Боровик А. Корупщійні практики та методи їх подолання у державах Європи. Підприємство, господарство і право. 2019. №5. С. 229-236.

8. Статути Великого князівства Литовського: У 3-х томах. Том I. Статут Великого князівства Литовського 1529 року / за ред. С. Ківалова. Одеса: Юридична література, 2002. 464 с.

9. Жаленко Н. Історичні аспекти виникнення корупції в Україні. Правові горизонти. 2019. № 15. C. 7 - 12.

10. Szymon Starowolski «Lament Utrapiony Matki Korony Polskiej». URL: https:/ / books. google.com.ua/books?id=jm1bAAAAQAAJ\&printsec=frontcover\&hl=uk\&source=gbs_ge_sum mary_r\&cad=0\#v=onepage\&q\&f=false (дата доступу: 28.05.2020).

11. Договори і постанови прав і свобод військових між Ясновельможним Його Милості паном Пилипом Орликом, новообраним гетьманом Війська Запорізького, і між генеральними особами, полковниками і тим же Військом Запорізьким з повною згодою з обох сторін: від 05.04.1710. URL: http:/ / gska2.rada.gov.ua/site/const/istoriya/1710.html (дата доступу: 28.05.2020).

12. Утвенко В. В. Зловживання службовим становищем в Україні в роки гетьманування Кирила Розумовського та антикорупщійні заходи Гетьманського уряду. URL: https:/ / ir.kneu.edu.ua/bitstream/handle/2010/23871/124-136.pdf?sequence=1\&isAllowed=y

13. Левицька Н. Чорна рада - ефект українських граблів? URL: https:/ / fakeoff.org/history/chorna-rada-efekt-ukrainskikh-grabliv (дата звернення: 28.05.2020).

14. Гаращук В. М. Актуальні проблеми боротьби з корупщією. Харків: Право, 2010.144 с.

15. Епархина О. В. Моделирование коррупщии. Ярославский педагогический вестник. 2013. № 1. C. 110 -116.

16. Мелкевік Б. Поезія як стійкість: викриття тиші й байдужості (толерантність до несправедливості як загроза демократії і правам людини). Філософія права $і$ загальна теорія права. 2014. № 1-2. С. 429-441.

17. Коррупционная семерка: самые громкие дела в CCCP. URL: https://mir24.tv/articles/16309896/korrupcionnaya-semerka-samye-gromkie-dela-v-sssr (дата звернення: 28.05.2020).

\section{References:}

1. Havrylenko, O. A. (2011) Istoriia derzhavy i prava Ukrainy: starodavnia doba : navch. posib. Kharkiv: KhNUVS. [in Ukrainian].

2. Rusyaeva, A. S. (2010) O prisyage grazhdan Khersonesa Tavricheskogo i zagadochnom slove $\Sigma$ A $\Sigma$ TNRA. Bosporskie issledovaniya- Bosporus research, issue XXIII, 212-191. [in Ukrainian].

3. Maskovita, M. M. (2017) Prysiaha pratsivnykiv OVS Ukrainy: istoryko-pravovyi vymir. Candidate's thesis. Lvivskyi universytet vnutrishnikh sprav. Lviv. [in Ukrainian].

4. Voitovych, L. V.(2015) Kniaz Volodymyr Sviatoslavych (Sviatyi rivnoapostolnyi kniaz Volodymyr). Visnyk Lvivskoi komertsiinoi akademii. Humanitarni nauky-Bulletin of the Lviv Commercial Academy. Humanities. Lviv, issue 13, 7 -18. [in Ukrainian].

5. Pravda ruska. Teksty na osnovi 7 spyskiv ta 5 redaktsii. (1935) S. Yushkov (Ed.). Kyiv: VUAN, 137-144. URL: http://litopys.org.ua/oldukr2/oldukr51.htm. [in Ukrainian].

6. Pokhodzilo, Yu. M. (2017) Stanovlennia podatkovoi funktsii derzhavy na ukrainskykh zemliakh u chasy Kyivskoi Rusi ta feodalnoi rozdroblenosti XII - XIV st. Pravo ta innovatsii- Law and innovation, 4(20), 69-74. [in Ukrainian].

7. Borovyk, A. (2019) Koruptsiini praktyky ta metody yikh podolannia u derzhavakh Yevropy. Pidpryiemstvo, hospodarstoo i pravo - Enterprise, economy and law, № 5, 229-236. [in Ukrainian]. 
8. Statuty Velykoho kniazivstva Lytovskoho. (2002) Vol. 1-3; Vol. 1. Statut Velykoho kniazivstva Lytovskoho 1529 roku. S. Kivalov (Ed.). Odesa: Yurydychna literatura. [in Ukrainian].

9. Zhalenko, N. (2019) Istorychni aspekty vynyknennia koruptsii v Ukraini. Pravovi horyzonty-Legal horizons, 15, 7 - 12. [in Ukrainian].

10. Szymon Starowolski «Lament Utrapiony Matki Korony Polskiej». N. d. URL: https:/ / books.google.com.ua/books?id=jm1bAAAAQAAJ\&printsec $=$ frontcover\&hl=uk\&source=gbs_g e_summary_r\&cad $=0 \# \mathrm{v}=$ onepage\& $\mathrm{q} \& \mathrm{f}=$ false. [in Ukrainian].

11. Dohovory i postanovy prav i svobod viiskovykh mizh Yasnovelmozhnym Yoho Mylosti panom Pylypom Orlykom, novoobranym hetmanom Viiska Zaporizkoho, i mizh heneralnymy osobamy, polkovnykamy i tym zhe Viiskom Zaporizkym z povnoiu zghodoiu z obokh storin: vid 05.04.1710. (1710) N. p. URL: http://gska2. rada. gov.ua/site/ const/ istoriya/1710.html. [in Ukrainian].

12. Utvenko, V. V.Zlovzhyvannia sluzhbovym stanovyshchem v Ukraini v roky hetmanuvannia Kyryla Rozumovskoho ta antykoruptsiini zakhody Hetmanskoho uriadu. N d. N. p. URL: https:/ / ir.kneu.edu.ua/bitstream/handle/2010/23871/124-136.pdf?sequence=1\&isAllowed=y. [in Ukrainian].

13. Levytska, N. Chorna rada - efekt ukrainskykh hrabliv? N. d. N. p. URL: https:/ / fakeoff. org/history/chorna-rada-efekt-ukrainskikh-grabliv. [in Ukrainian].

14. Harashchuk, V. M. (2010) Aktualni problemy borotby z koruptsiieiu. Kharkiv: Pravo. [in Ukrainian].

15. Eparkhina, O. V. (2013) Modelirovanie korruptsii. Yaroslavskiy pedagogicheskiy vestnikYaroslavl Pedagogical Bulletin,1, 110-116. [in Russian].

16. Melkevik, B. (2014) Poezija jak stijkist: vykryttja tyshi i baiduzjosti (tolerantnist do nespravedlyvosti jak zahroza demokratiji i pravam ludyny). Philosophija prava I zahalna teorija pravaPhilosophy of law and general theory of law, 1-2, 429-441. [in Ukrainian].

17. Korrupcionnaja semerka: samye gromkie dela vSSSR. N/ d. N.p.URL:https:/ / mir24.tv/ articles/16309896/korrupcionnaya-semerka-samye-gromkie-dela-v-sssr. [in Ukrainian].

Стаття надійшиа до редколегіï 14.06.2020

Пилипенко В. В.,

кандидат исторических наук, старший преподаватель кафедры социально-гуманитарных дисциплин Луганского государственного университета

внутренних дел имени Э. А. Дидоренко (г. Северодонецк, Украина)

\section{КОРРУПЦИЯ НА УКРАИНСКИХ ЗЕМЛЯХ КАК ВОПРОС КУРСА ИСТОРИИ ГОСУДАРСТВА И ПРАВА}

Статья посвящена анализу способов получения неправовой выгоды на украинских землях в зависимости от их территориально-политической приналежндости в разные периоды истории Украины и развития правового регулирования предупреждения коррупщионной составляющей в деятельности должностных лищ или органов государственной власти. Исследовано основные проявления коррупщии от Киевской Руси до распада СССР; особое внимание уделено рассмотрению системы кормления, получению неправовой выгоды в виде подарков и презентов государственными служащими, тотальной коррумпированно- 
сти советского общества, что выражалось в виде блата, приписов и т.д. Установлено, что обращение к этому материалу и анализ исторических источников в контексте определения и противостояния коррупции способствует установлению межпредметных связей, что предполагает лучшее усвоение соответствующих профессиональных знаний как дисциплин гуманитарного цикла в ЗВО МВД Украины, так и специальных государственно-правовых, а также формирует активную гражданскую позицию в противодействии негативным общественным явлениям.

Ключевые слова: коррупщия, взятка, блат, подкуп, кормления, партийная номенклатура, неправовая выгода, профессиональные знания, гражданская позиция.

\author{
Pylypenko V., \\ Ph.D in History, \\ Lecturer of Department of Social disciplines, \\ Luhansk State University of Internal \\ affairs named after E. Didorenko \\ (Sievierodonetsk, Ukraine)
}

\title{
CORRUPTION ON THE UKRAINIAN LANDS AS AN ISSUE OF THE COURSE "HISTORY OF STATE AND LAW"
}

The article is devoted to the analysis of ways to obtain illegal benefits in the Ukrainian lands depending on their territorial and political affiliation and the development of legal regulation to prevent corruption in the activities of officials or public authorities.

It is noted that one of the first documentary evidence of attempts to combat corruption was the Oath of the Citizen of Chersonesos, which contained the obligation of every citizen not to act to the detriment of the city-state.

Attention is drawn to the analysis of the system of "feeding" in Kievan Rus, as a type of abuse of power by officials, which inevitably led to illegal corruption.

It was found that for the XVII - XVIII centuries. the involvement and mercenary nature of judges, the trade in Cossack sergeant positions, the extortion of money for the favorable redistribution of the lands of the Hetmanate, or the liberation of the Cossacks from campaigns became commonplace.

Founded in the XIX century. The tradition of giving gifts to officials to quickly resolve the issue in the Soviet period has reached unprecedented proportions, which suggests the existence of entire corruption schemes, which could not be overcome even by the Soviet government with its totalitarian methods of leadership.

It is established that the analysis of historical sources in the context of detecting and combating corruption contributes to the establishment of interdisciplinary links, promoting better learning in both the disciplines of the humanities and special state law. In addition, examples of high-profile corruption scandals can be used for master's cases in the study of such a discipline as "Logic".

Further prospects for the study may be published didactic materials of binary lectures on history and a particular field of law, where historical experience can only improve students' perception of the material through clarity or interesting historical facts.

Keywords: corruption, bribery, bribery, bribery, feeding, party nomenclature, illegal profit, professional knowledge, citizenship. 